\title{
Trophic diversity of Poznań Lakeland lakes
}

\author{
Piotr Dzieszko, Zbigniew Zwoliński \\ Department of Geoinformation, Institute of Geoecology and Geoinformation, Adam Mickiewicz University in Poznań, \\ Dzięgielowa 27,60-681 Poznań, Poland, e-mail: dzieszko@amu.edu.pl,zbzw@amu.edu.pl
}

\begin{abstract}
The main goal of the presented work is to determine the current trophic state of 31 lakes located in Poznań Lakeland. These lakes are included in the lake monitoring programme executed by the Voivodship Environmental Protection Inspectorate in Poznań. The place in the trophic classification for investigated lakes was determined as well as the relationships between their trophic state indices. The trophic state of investigated lakes in the research area is poor. More than a half of the investigated lakes are eutrophic. Depending on the factor that is taken into account the trophic state of investigated lakes differs radically.
\end{abstract}

Key words: trophic state index, trophic classification, Carlson's model, Poznań Lakeland

\section{Introduction}

Lakes play a very special role in the landscape structure of Poland. They influence water circulation, sedimentation of mineral and organic matter. Lake catchments are a very important landscape structure in the geographical environment. Lakes are also a subject of interdisciplinary research which has theoretical and practical significance in landscape studies (Kostrzewski 2008).

Lakes constitute the main element of the hydrographic network of young glacial areas. They differ in morphometric parameters of their basins, size of drainage area and their role in the hydrological cycle. Protection of lake ecosystems and their rational exploitation is very important in conditions of growing human impact on the environment (BajkiewiczGrabowska 2008).

For the recognition of the functioning state of every water reservoir it is crucial to recognize its trophic state (Zdanowski 1982; Napiórkowska-Krzebietke et al. 2007; Bajkiewicz-Grabowska 2008; Jarosiewicz et al. 2011; Jarosiewcz, Fryda 2011; Bekteshi, Cupi 2014). It allows the determining of the biotic and abiotic relationships which are present in the water column (Carlson and Simpson 1996; Kiersztyn et al. 2002; Matthews et al. 2002). The main goal of the pre- sented work is to determine the current trophic state of 31 lakes located in Poznań Lakeland. These lakes are included in the lake monitoring programme executed by Voivodship Environmental Protection Inspectorate in Poznan. The place in the trophic classification for the investigated lakes was determined as well as relationships between their trophic state indices.

\section{Study area}

The area of interest presented in this work is Poznań Lakeland (Fig. 1). It is located in the centralwestern part of Poland. The vast majority of its area is located in Greater Poland Voivodship. A small, the most western, part belongs to Lubusz Voivodship. It is a very differential landscape with agricultural areas as an absolutely dominating land cover class. The total area of Poznań Lakeland equals $4158 \mathrm{~km}^{2}$. About 70\% of its surface is agricultural areas, and more than $25 \%$ is covered by forests. The limnic ratio for this region is $1.8 \%$. The total number of lakes regardless of their area according to the Hydrographic Division Map of Poland is 2442 .

The basic morphometric characteristics of investigated lakes are presented in Table 1 . They suggest that morphometric differentiation among the whole dataset is significant. Only small and medium lakes 


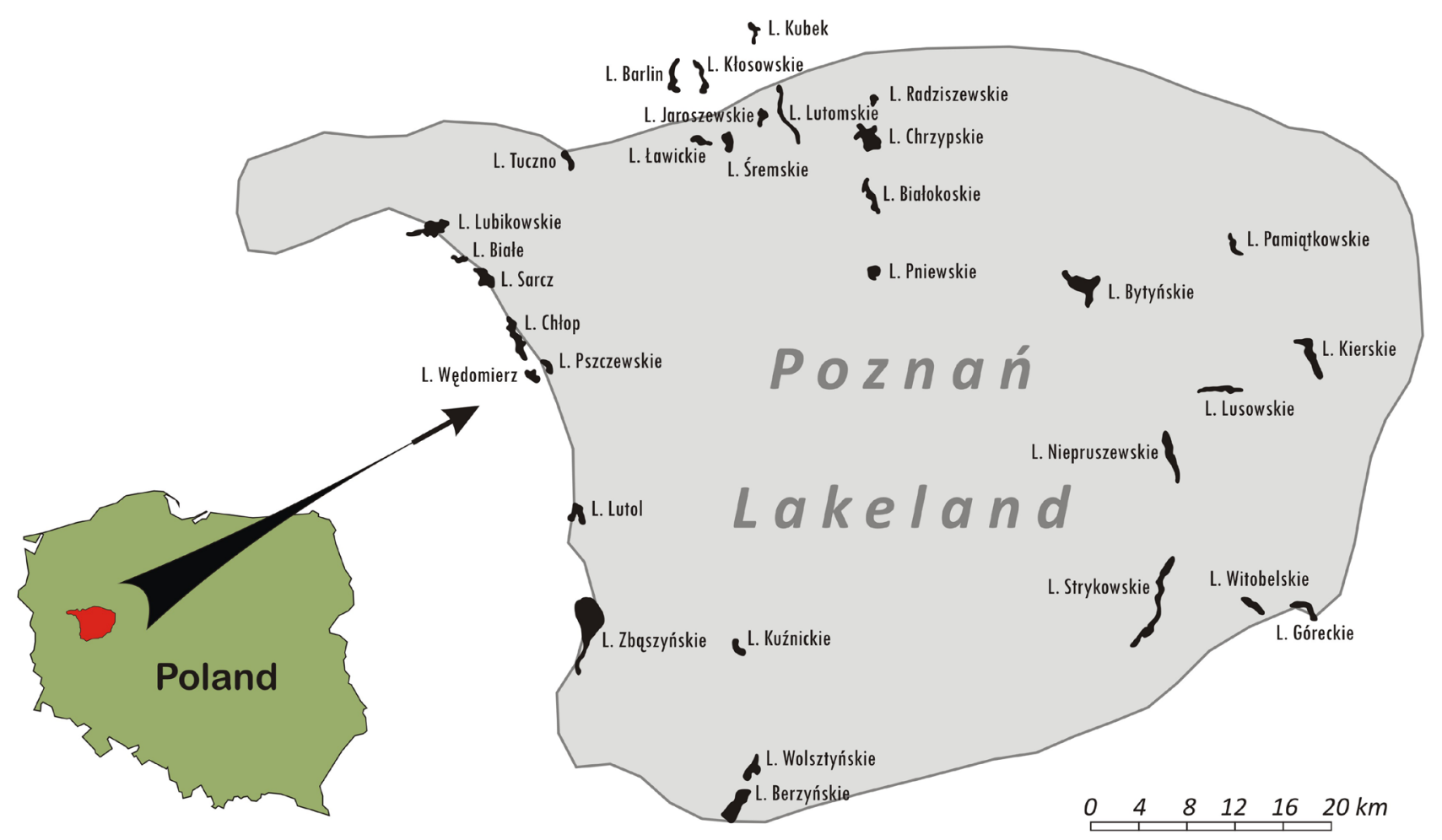

Fig. 1. Location of the research area and investigated lakes according to computer map of hydrographic division

Table 1. Selected descriptive statistics of morphometric data for investigated lakes based on data gathered by Voivodship Environmental Protection Inspectorates in Poznań and Zielona Góra

\begin{tabular}{lcccc}
\hline & N & Min & Max & Average \\
\hline Area [ha] & 31 & 40.00 & 742.50 & 170.04 \\
\hline Average depth [m] & 31 & 1.50 & 20.70 & 6.50 \\
\hline Max depth [m] & 31 & 3.20 & 45.00 & 15.76 \\
\hline Volume [thousands of $\left.{ }^{3}\right]$ & 31 & 898.70 & 34842.10 & 10625.92 \\
\hline Shoreline length $\left[\mathrm{km}^{2}\right.$ & 31 & 2.63 & 195.00 & 84.90 \\
\hline Catchment area $\left[\mathrm{km}^{2}\right]$ & 31 & 4.25 & 57.13 & 20.07 \\
\hline
\end{tabular}

according to Water Framework Directive (WFD) are present in the research area (Kolada et al. 2005). According to WFD small lakes have an area between 50 and 100 ha and medium lakes have an area between 100 and 1000 ha. The biggest lake in Poznań Lakeland has an area of 742 ha what means that there are no big lakes amongst the dataset. Among the investigated lakes there are shallow ones (i.e. Lake Barlin - average depth $1.5 \mathrm{~m}$ ), and deep lakes (i.e. Lake Śremskie - average depth $20.7 \mathrm{~m}$ ) according to Water Framework Directive (Kolada et al. 2005). There are also lakes with a short shoreline (i.e Lake Radziszewskie - shore- line length $2.63 \mathrm{~km}$ ) as well as lakes with shorelines longer by about two orders of magnitude (i.e Lake Strykowskie - shoreline length $195 \mathrm{~km}$ ).

\section{Methods}

Qualitative data was obtained on the basis of publications and unpublished works of Voivodship Environmental Protection Inspectorates in Poznań and Zielona Góra employees. These data are presented in Table 2. The trophic state of the investigated lakes was evaluated on the basis of three characteristic val- 
Table 2. Measurement values of Secchi disc depth (SD), chlorophyll $a$ concentration in the epilimnion zone (Chl $a$ ), total phosphorus concentration (TP), and trophic state indices values (based on data gathered from Voivodship Environmental Protection Inspectorates in Poznań and Zielona Góra)

\begin{tabular}{|c|c|c|c|c|c|c|c|c|c|}
\hline \multirow{2}{*}{ Lake } & SD & $\mathrm{Chl} \mathrm{a}$ & TP & \multirow{2}{*}{$\mathrm{TSI}_{\mathrm{SD}}$} & \multirow{2}{*}{$\mathrm{TSI}_{\mathrm{Chl}}$} & \multirow{2}{*}{$\mathrm{TSI}_{\mathrm{Tp}}$} & \multirow{2}{*}{ Mean TSI } & \multirow{2}{*}{ Trophic state } & \multirow{2}{*}{ Year } \\
\hline & $\mathrm{m}$ & $\mu \mathrm{g} \mathrm{dm^{-3 }}$ & $\mu \mathrm{g} \mathrm{dm}^{-3}$ & & & & & & \\
\hline Lubikowskie & 6.3 & 1.9 & 0.021 & 33 & 46 & 48 & 42 & mesotrophy & 2010 \\
\hline Szarcz & 3.4 & 1.5 & 0.014 & 42 & 44 & 42 & 43 & mesotrophy & 2010 \\
\hline Tuczno & 3.7 & 4.5 & 0.032 & 41 & 54 & 54 & 50 & mesotrophy & 2012 \\
\hline Białe & 2.5 & 9.1 & 0.025 & 47 & 61 & 51 & 53 & mesotrophy & 2012 \\
\hline Pszczewskie & 3.2 & 10.9 & 0.039 & 43 & 63 & 57 & 54 & mesotrophy & 2012 \\
\hline Śremskie & 3.0 & 7.0 & 0.064 & 44 & 59 & 64 & 56 & mesotrophy & 2012 \\
\hline Kuźnickie & 3.6 & 16.2 & 0.045 & 42 & 67 & 59 & 56 & mesotrophy & 2008 \\
\hline Ławickie & 2.1 & 15.7 & 0.034 & 49 & 67 & 55 & 57 & mesotrophy & 2010 \\
\hline Lusowskie & 3.6 & 9.9 & 0.087 & 42 & 62 & 69 & 57 & mesotrophy & 2012 \\
\hline Chłop & 2.7 & 14.7 & 0.061 & 46 & 66 & 63 & 58 & mesotrophy & 2010 \\
\hline Wędromierz & 1.7 & 17.8 & 0.040 & 52 & 68 & 57 & 59 & mesotrophy & 2012 \\
\hline Jaroszewskie & 2.3 & 15.7 & 0.071 & 48 & 67 & 66 & 60 & mesotrophy & 2010 \\
\hline Pamiątkowskie & 1.0 & 39.6 & 0.028 & 60 & 76 & 52 & 63 & eutrophy & 2008 \\
\hline Chrzypskie & 2.7 & 15.0 & 0.152 & 46 & 66 & 77 & 63 & eutrophy & 2010 \\
\hline Góreckie & 2.4 & 16.4 & 0.200 & 47 & 67 & 81 & 65 & eutrophy & 2011 \\
\hline Lutomskie & 1.8 & 31.7 & 0.098 & 52 & 74 & 70 & 65 & eutrophy & 2012 \\
\hline Białokoskie & 0.9 & 35.0 & 0.056 & 62 & 74 & 62 & 66 & eutrophy & 2011 \\
\hline Barlin & 0.8 & 54.2 & 0.040 & 63 & 79 & 57 & 66 & eutrophy & 2010 \\
\hline Bytyńskie & 0.8 & 42.5 & 0.054 & 63 & 76 & 62 & 67 & eutrophy & 2012 \\
\hline Kierskie & 1.4 & 30.2 & 0.167 & 55 & 73 & 78 & 69 & eutrophy & 2011 \\
\hline Kłosowskie & 0.7 & 45.9 & 0.078 & 65 & 77 & 67 & 70 & eutrophy & 2011 \\
\hline Kubek & 0.9 & 62.0 & 0.126 & 62 & 80 & 74 & 72 & eutrophy & 2010 \\
\hline Pniewskie & 0.6 & 62.1 & 0.092 & 67 & 80 & 69 & 72 & eutrophy & 2008 \\
\hline Niepruszewskie & 0.8 & 71.3 & 0.133 & 63 & 81 & 75 & 73 & eutrophy & 2010 \\
\hline Strykowskie & 0.8 & 88.0 & 0.136 & 63 & 84 & 75 & 74 & eutrophy & 2010 \\
\hline Wolsztyńskie & 0.7 & 86.4 & 0.190 & 65 & 83 & 80 & 76 & eutrophy & 2008 \\
\hline Radziszewskie & 0.8 & 69.2 & 0.337 & 63 & 81 & 88 & 78 & eutrophy & 2010 \\
\hline Berzyńskie & 0.6 & 121.9 & 0.216 & 67 & 87 & 82 & 79 & eutrophy & 2012 \\
\hline Lutol & 0.6 & 117.6 & 0.238 & 67 & 86 & 83 & 79 & eutrophy & 2012 \\
\hline Zbąszyńskie & 0.6 & 109.2 & 0.303 & 67 & 86 & 87 & 80 & hypertrophy & 2012 \\
\hline Witobelskie & 0.5 & 174.4 & 0.395 & 70 & 90 & 90 & 84 & hypertrophy & 2005 \\
\hline
\end{tabular}

ues: Secchi disc visibility (SD), concentration of total phosphorus (TP) and concentration of chlorophyll $a$ in the epilimnion zone. Carlson's method (1977) was used for this purpose. Measurements were collected in one measuring position, in the deepest spot of the lake. They were carried out during the summer (July and August) in the phase of maximum development of summer stratification. Lenard, Ejankowski (2012) point out that the optimal solution is at least two se- ries of measurements carried out within two years. Calculations for lakes of Poznań Lakeland made on the basis of various series of field measurements carried out in 2005-2012.

In accordance with Carlson's method Trophic State Indices were determined on the basis of three main characteristic measurements. Three following equations determined by Carlson (1977) were used: 


$$
\begin{gathered}
T S I_{S D}=10\left(6-\frac{\ln S D}{\ln 2}\right) \\
T S I_{C h l}=10\left(6-\frac{2,04-0,68 \ln C h l}{\ln 2}\right) \\
T S I_{T P}=10\left(6-\frac{\ln \frac{48}{T P}}{\ln 2}\right)
\end{gathered}
$$

where: TSI $_{S D}$ is the Trophic State Index calculated using visibility of the Secchi disc characteristic (in metres), while TSI $_{\mathrm{Chl}}$ is the Trophic State Index calculated using the concentration of chlorophyll $a\left(\mu \mathrm{g} \mathrm{dm}^{-3}\right)$ in the epilimnion zone, and TSI ${ }_{\mathrm{TP}}$ is Trophic State Index calculated using the concentration of total phosphorus $\left(\mu \mathrm{g} \mathrm{dm}^{-3}\right)$.

If we take a look at the data collected in Table 2 it is worth seeing that 14 of 31 investigated lakes had a value of Secchi disc visibility less than 1 metre. Secchi disc visibility values vary from $3.4 \mathrm{~m}$ (Lake Szarcz) to $0.5 \mathrm{~m}$ (Lake Witobelskie). Lake Lubikowskie deviates from other lakes significantly. With Secchi disc visibility about $6.3 \mathrm{~m}$ this lake has the best trophic conditions among lakes in the whole dataset.

Relative TSI value lower than 40 characterizes the oligotrophic state of the lake water, values between 40 and 60 indicate the mesotrophic state of the lake water, values between 60 and 80 indicate the eutrophic state of the lake water while values higher than 80 indicate hypertrophy (Bajkiewicz-Grabowska 2007). Results of the measurements as well as calculated TSI values are presented in Table 2.

Graphical juxtaposition of the calculated indices was performed on Figure 2. It is worth noting that as a result of this analysis TSI based on Secchi disc visibility are lower than TSI based on the concentration of total phosphorus and the concentration of chlorophyll $a$ in the epilimnion zone according to the Carlson's model. It is also possible to notice that the majority of the dataset lies above the diagonal of the constructed graph (Fig. 2). It means that in the vast majority of the investigated cases the concentration of total phosphorus is higher than the corresponding visibility of Secchi disc value according to the Carlson's model. A very similar situation can be observed when we consider the value of the concentration of chlorophyll $a$ in the epilimnion zone. Data for every investigated lake lie above the diagonal of the graph.
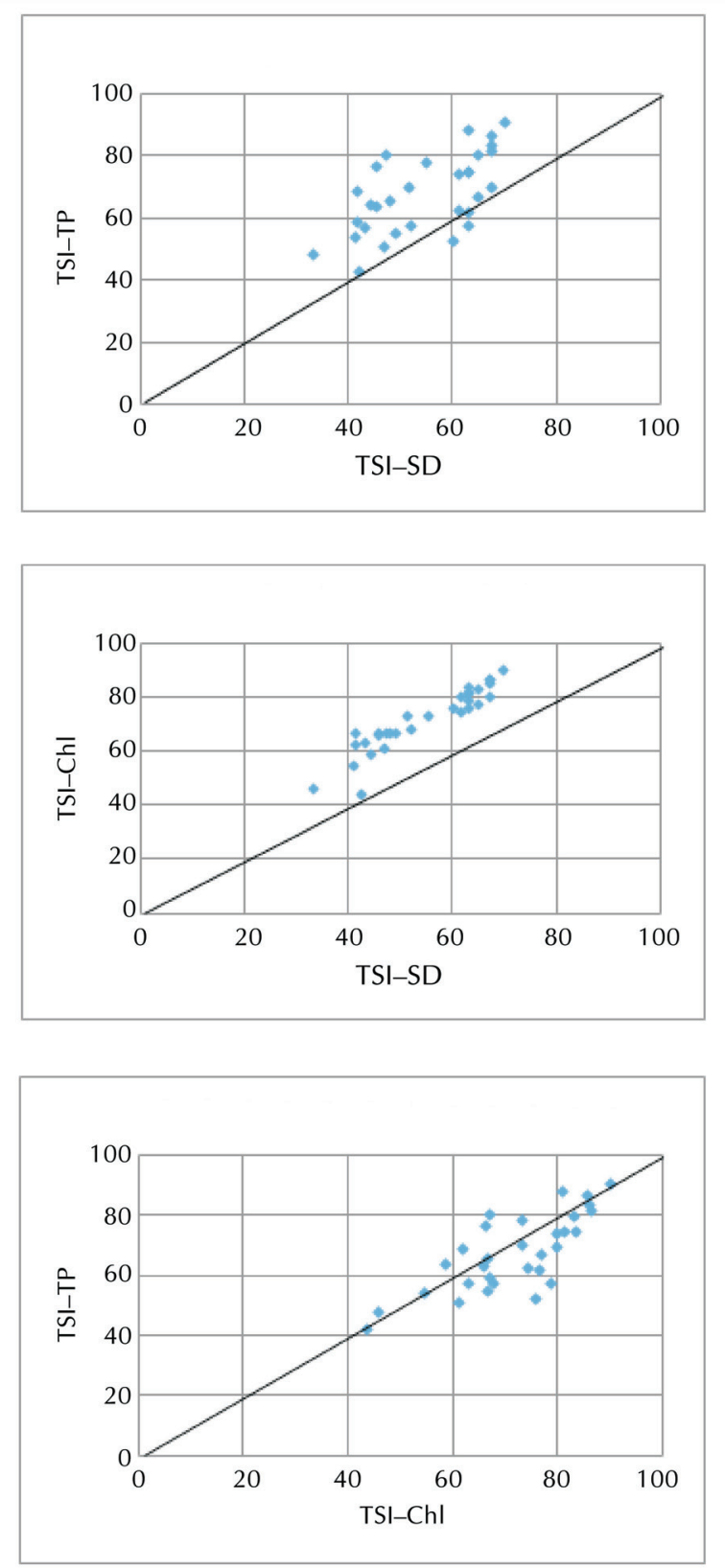

Fig. 2. Graphical juxtapositions of the Trophic State Indices for investigated lakes

When we consider TSI based on the concentration of total phosphorus and the concentration of chlorophyll in the epilimnion zone the observed pattern is much more differentiated. In the vast majority of lakes the concentration of chlorophyll is lower than the corresponding concentration of total phosphorus according to the Carlson's model. But what is also important, in this graphical juxtaposition data lies closer to the diagonal than in the other two graphs. It in- 


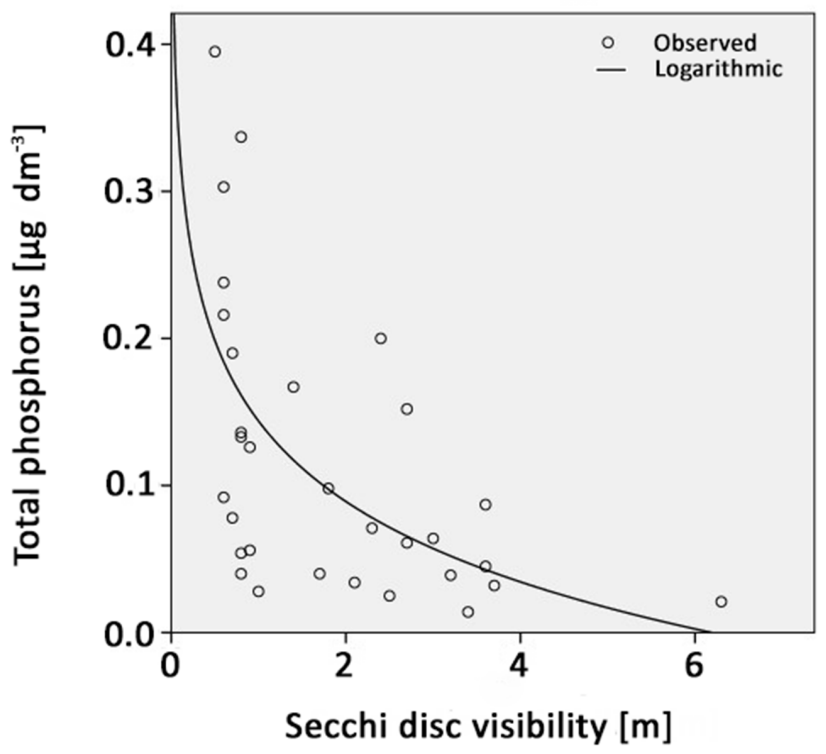

Fig. 3. The relationship between total phosphorus concentration $\left(\mu \mathrm{g} \mathrm{dm}^{-3}\right)$ and Secchi disc depth $(\mathrm{m})$ for 31 lakes located in the Poznań Lakeland

dicates just small discrepancies between TSI values based on TP and chlorophyll. When all TSI indices are equal, it means that the development of the lake is harmonic and undisturbed by human activity (Bajkiewicz-Grabowska 2007). Information about differences between individual TSI indices allows the determination of which factors limit the productivity of the lake.

\section{Results}

21 of 31 investigated lakes $(68 \%)$ represent a $\mathrm{TSI}_{\mathrm{TP}}$ value higher than $\mathrm{TSI}_{\text {Chl. }}$ It means that phosphorus is a biogen which limits biological productivity in more than $2 / 3$ of lakes in the research region. It was also investigated that the basic trophy state index concentration of total phosphorus in the lake - can be a good predictor for the other two trophy state indices which are normally considered in the literature as a symptomatic indicators. The relationships between TP and SD values were determined as well as relationships between TP and Chl values. As we can observe

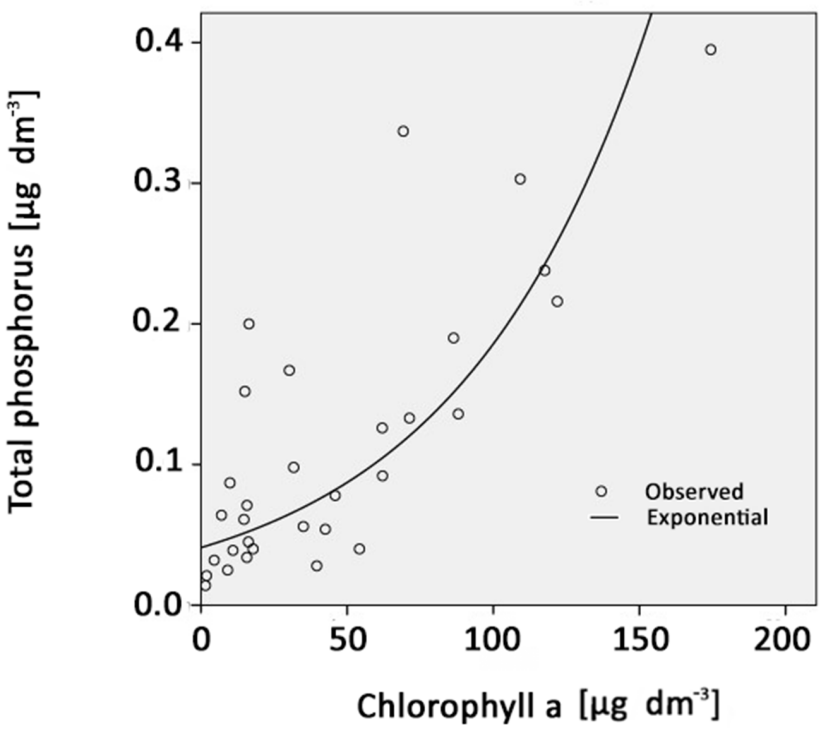

Fig. 4. The relationship between total phosphorus concentration $\left(\mu \mathrm{g} \mathrm{dm}^{-3}\right)$ and chlorophyll $a$ concentration $\left(\mu \mathrm{g} \mathrm{dm}{ }^{-3}\right)$ for 31 lakes located in the Poznan Lakeland

on Figures 3 and 4, the concentration of total phosphorus value is not the best predictor for symptomatic indicators in Poznan Lakeland District. The quality of models expressed by the coefficient of determination $\left(\mathrm{R}^{2}\right)$ is very similar to the coefficient of determination values obtained by Bajkiewicz-Grabowska (2007) for 33 lakes located in the Kashubian Landscape Park (Table 3). However, in the Kashubian Landscape Park the concentration of chlorophyll $a$ was much higher while water transparency was much lower than corresponding values of the total phosphorus concentration according to the Carlson's model. In the majority of the Poznań Lakeland lakes chlorophyll a concentration is a little higher than the corresponding total phosphorus ones, and much higher than the corresponding transparency values. The research revealed that, similar to the investigation performed by BajkiewiczGrabowska (2007) in the Kashubian Landscape Park, it is not possible to use the SD-TP and Chl-TP regression model for symptomatic trophy state indicator prediction.

Table 3. Statistical summary for relationships of Trophic State Indices

\begin{tabular}{cccccc}
\hline Relationship & Model & $r$ & $\mathrm{R}^{2}$ & Adjusted $\mathrm{R}^{2}$ & Standard error \\
\hline TP - SD & logarithmic & 0.582 & 0.338 & 0.316 & 0.082 \\
\hline TP - Chl & exponential & 0.736 & 0.541 & 0.525 & 0.603 \\
\hline SD - Chl & logarithmic & 0.904 & 0.817 & 0.810 & 0.597 \\
\hline
\end{tabular}


A statistical summary of the TP-SD and SDChl logarithmic models and the TP-Chl exponential model is presented in Table 3. The values of statistical measures in Table 3 are weaker than those presented by Carlson (1977), due to the smaller number of investigated lakes in the Poznan Lakeland.

For the model based on the natural logarithm and relationship between SD and Chl the coefficient of determination was also calculated. It appeared that similar to 33 lakes in the Kashubian Landscape Park also in Poznan Lakeland the coefficient of determination was highest for this relationship $\left(\mathrm{R}^{2}=0.817\right)$ (Fig. 5, Table 3). This fact indicates that even in quite different research areas the correlation between water transparency and concentration of chlorophyll $a$ is normally high. So, Secchi disc depth can be a good predictor for chlorophyll $a$ for studied lakes (Fig. 5). A statistical summary of the SD-Chl logarithmic model is presented in Table 3.

The diagram of relationships between TSI for investigated lakes can be seen in Figure 6. On the vertical axis there are values $\mathrm{TSI}_{\mathrm{Ch}}-\mathrm{TSI}_{\mathrm{TP}}$. The horizontal axis

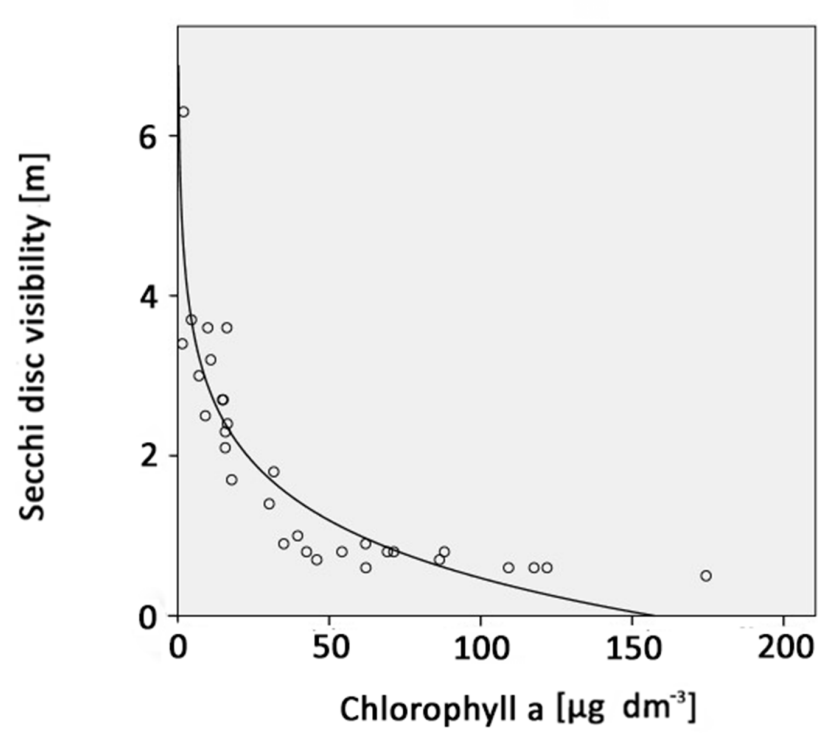

Fig. 5. The relationship between Secchi disc depth (m) and chlorophyll $a$ concentration $\left(\mu \mathrm{g} \mathrm{dm}^{-3}\right)$ for 31 lakes located in the Poznań Lakeland

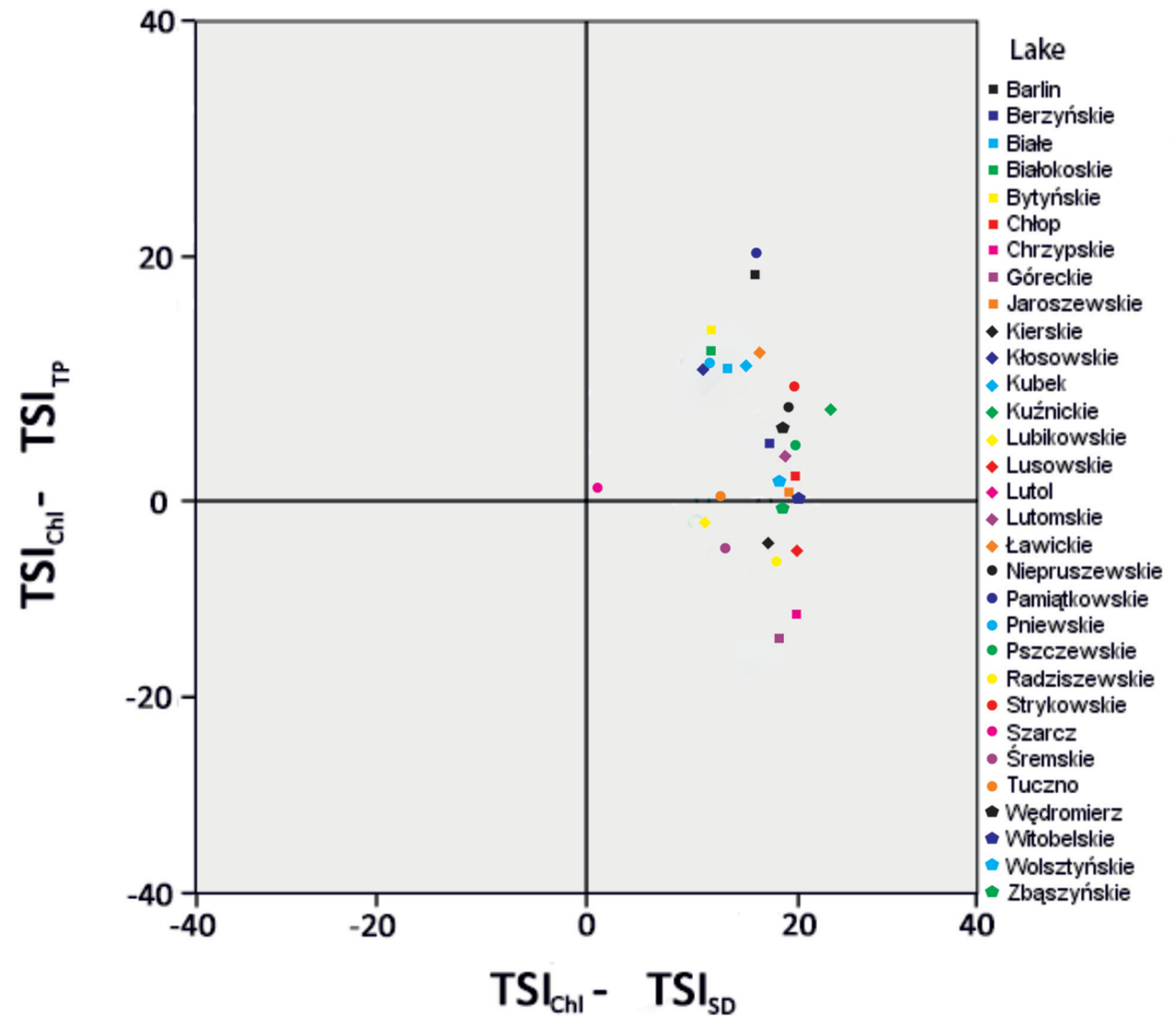

Fig. 6. Diagram of relationships between TSI for investigated lakes 
demarcates the area in the graph which indicates biogen limitation. If points representing individual lakes in the dataset lie above the horizontal axis, it means that there is a high probability of phosphorus limitation. $68 \%$ of investigated lakes lie above the horizontal axis. On the horizontal axis there are values of $\mathrm{TSI}_{\mathrm{Chl}}-\mathrm{TSI}_{\mathrm{SD}}$. Points located on the right side of the vertical axis indicate the situation where the water transparency is higher than it would result calculated from TP value and $\mathrm{TSI}_{\mathrm{TP}}$ value. This is present in lakes where phytoplankton is dominated by relatively large autotrophic plants (BajkiewiczGrabowska 2007). It is observed in every investigated lake located in the research area.

The trophic state of the investigated lakes differs depending on which TSI is taken into account. If we take a look at Figure 7, we can observe that if we take into account TSI based on SD value, then just 3\% of the lakes can be considered as oligotrophic lakes. About half of the lakes are then considered as mesotrophic and eutrophic. If we take into account in determining the trophic state of the lakes just the $\mathrm{TSI}_{\mathrm{Chl}}$ value, then one third of the investigated lakes should be considered as hypertrophic and more than a half of them should be considered as eutrophic. Oligotrophic lakes cannot be observed in this case. This leads to the conclusion that lakes located in Poznan Lakeland are not harmonically developed and probably anthropogenic disturbance has a strong influence on them. This conclusion is based on the assumption that if each lake has similar values of all trophic status indicators, lake water are homogeneous. If the lake is characterized by the different types and values of trophic status indicators, it means that the nature of lake waters is significantly transformed by human activity.

The trophic state of the investigated lakes was also compared with research conducted in other parts of Poland. The summary of this comparison is presented in Table 4. Amongst the studies conducted in Poland that used the Carlson method (1977) to assess the water quality, lakes located in Poznań Lakeland are one of the most trophic and transformed by the human activity. This state of affairs is most likely associated with a high percentage of agricultural areas (67\%) in the Poznan Lakeland.

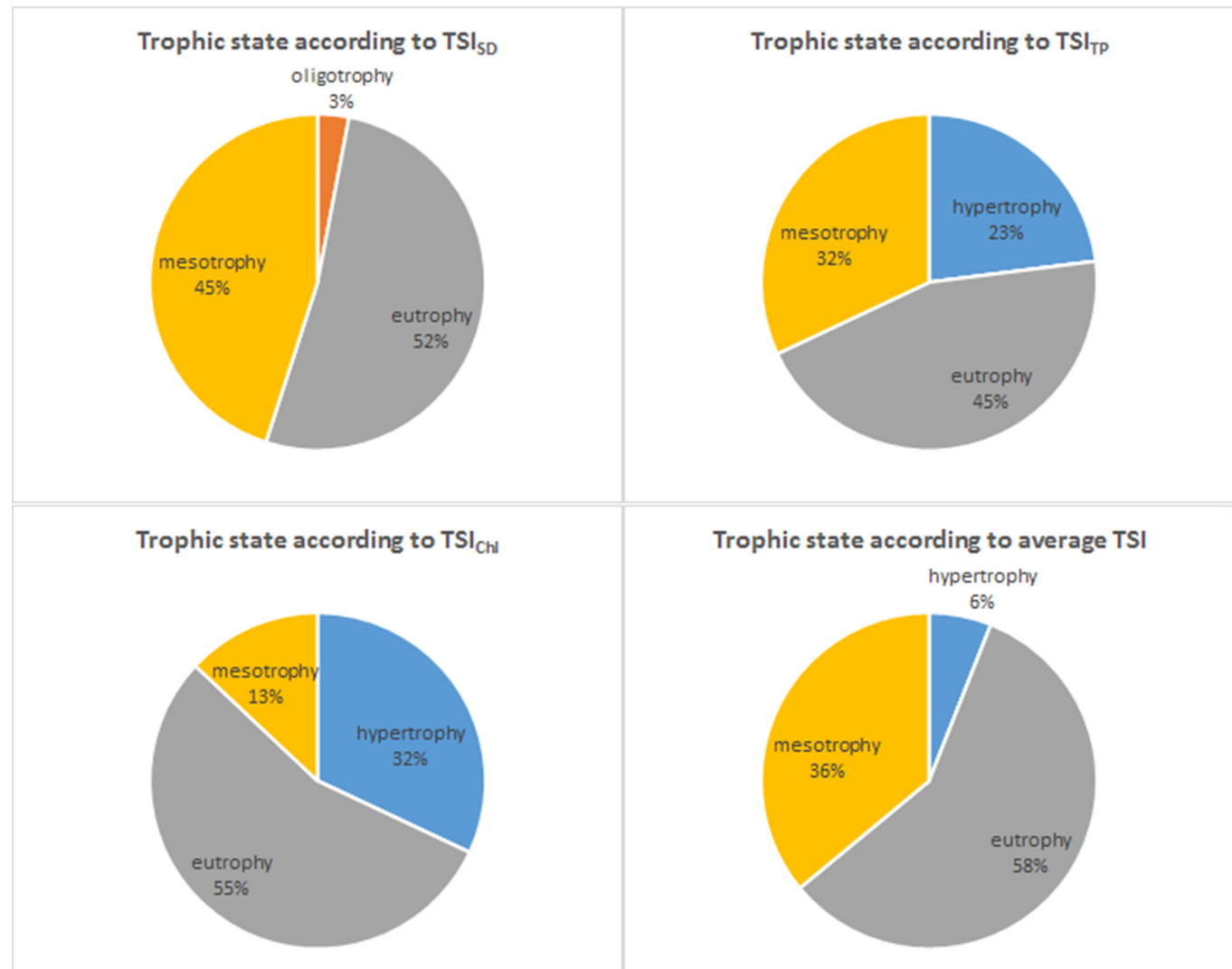

Fig. 7. Changes in the percentage of the Poznań Lakeland lakes with different trophic state depending on the TSI index used for trophy determination 


\section{Conclusions}

According to the results presented in Table 4 it can be concluded that the trophic state of the investigated lakes in the research area is poor. Worse trophic states were found only in the work of Pełechata et al. (2006) for the Lubusz Lakeland but please note that in the work of Pełechata et al.(2006) authors used different way of trophic state determination (Table 4) so this result are not straight comparable. More than a half of the investigated lakes are eutrophic. There are also further conclusions from the presented work:

$\Rightarrow 68 \%$ of the investigated lakes have a $\mathrm{TSI}_{\mathrm{TP}}$ value higher than $\mathrm{TSI}_{\mathrm{Ch}}$, which means that the phosphorus is limiting biological productivity in the majority of lakes located in Poznań Lakeland,

$\Rightarrow$ Concentration of chlorophyll $a$ in the epilimnion zone with no doubt overstates the values of average TSI while transparency decreases it,

$\Rightarrow$ Depending on which water quality parameter is taken into consideration the trophic state of the investigated lakes differs radically,

$\Rightarrow$ It must be taken into account that when considering only the TSI value for transparency $\left(\mathrm{TSI}_{\mathrm{SD}}\right.$ ), $3 \%$ of the investigated lakes should be presumed oligotrophic while hypertrophic ones are absent in the investigated research area,

$\Rightarrow$ When the trophic state index for chlorophyll $a$ $\left(\mathrm{TSI}_{\mathrm{Chl}}\right)$ is taken into account only, then $32 \%$ of the investigated lakes should be considered as hypertrophic ones, more than a half of them should be eutrophic ones, while oligotrophic ones are absent in this region,
$\Rightarrow$ When only trophic state index based on phosphorus concentration is taken into account then almost one quarter $(23 \%)$ of the investigated lakes number are hypertrophic, almost half of the investigated lakes number (45\%) are eutrophic and almost one third of the investigated lakes number (32\%) can be considered as mesotrophic.

Two final conclusions can be stated on the basis of the presented research. Concerning relationships between trophy state indices the investigated lakes from the Poznan Lakeland area are very similar to those located in the Kashubian Landscape Park and studied by Bajkiewicz-Grabowska (2007). But when the focus is on the water quality and functioning state expressed by trophy state indices, then it has to be concluded that the trophic state determined for the investigated lakes is poor, which is the effect of the human activity.

Excepting Lubusz Lakeland investigated by Pełechata et al. (2006) Poznań Lakeland dataset has the highest percentage of hyperthrophic water bodies in comparison to any work conducted in Poland using Carlsson method.

\section{Acknowledgments}

The presented work was financially supported by the National Science Centre (Poland), grant number 2013/09/N/HS4/03742 - "Modelling of humanenvironment relationships of Poznan Lakeland lake landscapes".

Table 4. Comaprison of trophic states of lakes from different regions in Poland. Trophy classification after Carlson, Simpson (1996): oligotrophy - OL (0-40); mesotrophy - ME (41-60); eutrophy - EU (61-80); hypertrophy - HE (>80)

\begin{tabular}{|c|c|c|c|c|c|c|c|c|}
\hline \multirow{2}{*}{ Region } & \multirow{2}{*}{$\begin{array}{l}\text { Number of } \\
\text { lakes }\end{array}$} & \multicolumn{4}{|c|}{ Trophic states [\%] } & \multirow{2}{*}{$\begin{array}{c}\text { Way of trophic } \\
\text { state determination }\end{array}$} & \multirow{2}{*}{$\begin{array}{l}\text { Trophic state } \\
\text { indicator }\end{array}$} & \multirow{2}{*}{ References } \\
\hline & & $\mathrm{OL}$ & ME & EU & $\mathrm{HE}$ & & & \\
\hline Kashubian Landscape Park & 33 & 0 & 24 & 73 & 3 & average value & $\mathrm{TSI}_{\mathrm{TP}}$ & Bajkiewicz-Grabowska (2007) \\
\hline Masurian and Suwałki Lakeland & 11 & 9 & 82 & 9 & 0 & average value & $\mathrm{TSI}_{\mathrm{TP}}$ & Pyka et al. (2007) \\
\hline West Pomerania & 12 & 0 & 50 & 50 & 0 & average value & $\mathrm{TSI}_{\mathrm{TP}}$ & Kubiak (2003) \\
\hline Słupia R. catchment & 23 & 0 & 74 & 26 & 0 & average value & $\mathrm{TSI}_{\mathrm{TP}}$ & Jarosiewicz and Fryda (2011) \\
\hline Poznań Lakeland & 31 & 0 & 36 & 58 & 6 & average value & $\mathrm{TSI}_{\mathrm{TP}}$ & this study \\
\hline Lubusz Lakeland & 33 & 0 & 12 & 70 & 18 & $\mathrm{TSI}_{\mathrm{TP}}$ & $\mathrm{TSI}_{\mathrm{TP}}$ & Pełechata et al. (2006) \\
\hline
\end{tabular}




\section{References}

Bajkiewicz-Grabowska E., 2007, Zróżnicowanie troficzne jezior - stan obecny, miejsce w klasyfikacji troficznej (Trophic diversity of lakes - present state, the place in the trophic classification), [in:] Borowiak D. (ed.), Jeziora Kaszubskiego Parku Krajobrazowego (Lakes of the Kashubian Landscape Park), Ser. Bad.Limnol. 5, Wydaw. KLUG, Gdańsk: 293-305 (in Polish, English summary).

Bajkiewicz-Grabowska E., 2008, Lake geoecosystems as an indicator of the rate of natural eutrophication of water reservoirs, Limnol. Rev. 8(1-2): 9-12.

Bekteshi A., Cupi A., 2014, Use of trophic state index (Carlson, 1977) for assessment of trophic status of the Shkodra Lake, Journal of Environmental Protection and Ecology 15(1): 359-365.

Carlson R.E., 1977, A trophic state index for lakes, Limnol. Oceanogr. 22: 361-369.

Carlson R.E., Simpson J. 1996, A coordinator's guide to volunteer lake monitoring methods, North American Lake Management Society, Madison, pp. 96.

Jarosiewicz A., Ficek D., Zapadka T., 2011, Eutrophication parameters and Carlson-type trophic state indices in selected Pomeranian lakes, Limnological Review 11(1): $15-23$.

Jarosiewicz A., Fryda E., 2011, Zróżnicowanie troficzne wybranych jezior zlewni rzeki Słupi (Trophic diversity of chosen lakes of the Słupia River catchment area), Słupskie Pr. Biol. 8: 51-65 (in Polish, English summary).

Kiersztyn B., Siuda W., Chróst R.J., 2002, Microbial ectoenzyme activity: useful parameters for characterizing the trophic conditions of lakes, Pol. J. Environ. Stud. 11:367373.
Kolada A., Soszka H., Cydzik D., Gołub M., 2005. Abiotic typology of Polish lakes. Limnologica 35: 145-150.

Kostrzewski A., 2008, Present state and functioning of lake geoecosystems - methodological and methodical assumptions, Limnol. Rev. 8(1-2): 5-8.

Kubiak J., 2003, Największe dimiktyczne jeziora Pomorza Zachodniego. Poziom trofii, podatność na degradację oraz warunki siedliskowe ichtiofauny (The largest dimictic lake of Western. Pomerania. Trophic status, susceptibility to degradation, and ichthyofauna habitat conditions), Rozpr. AR Szczec. 214, Szczecin, pp. 96 (in Polish, English summary).

Lenard T., Ejankowski W., 2012, Frequency of sampling in lake trophy estimation based on TSI indices, Monitoring Środowiska Przyrodniczego 13: 81-84.

Matthews R., Hilles M., Pelletier G,. 2002, Determining trophic state in Lake Whatcom, Washington (USA), a soft water lake exhibiting seasonal nitrogen limitation, $\mathrm{Hy}$ drobiologia 468(1): 107-121.

Napiórkowska-Krzebietke A., Wierzchowska M., Błocka B., Hutorowicz J., Hutorowicz A., Zdanowski B., 2007, Changes in the Trophic State of Lake Niegocin after the Modernization of a Local Wastewater Treatment Plant, Limnological Review 7(3): 153-159.

Pełechata A., Pełechaty M., Pukacz A., 2006, An attempt of the trophic status assessment of the lakes of Lubuskie Lakeland, Limnol. Rev. 6: 239-246.

Pyka J.P., Zdanowski B., Stawecki K., Prusik S., 2007, Trends in the environmental changes in the selected lakes of the Mazury and Suwałki Lakelands, Limnol. Rev. 7(2): 101-109.

Zdanowski B., 1982, Variability of nitrogen and phosphorus content and eutrophication, Pol. Arch. Hydrobiol. 29: 541-597. 